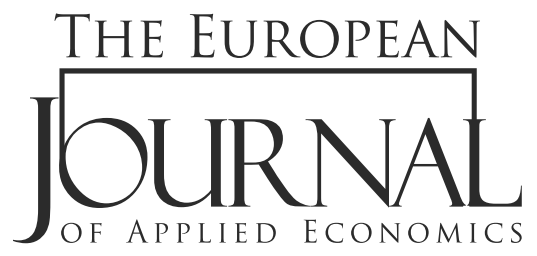

\title{
DO LARGE FIRMS BENEFIT MORE FROM R\&D INVESTMENT?
}

\section{Oyakhilome Ibhagui}

The African Institute for Mathematical Sciences (AIMS)

River Place, Arlington Blvd, Virginia

\begin{abstract}
:
We examine the importance of firm size in the relationship between research \& development $(\mathrm{R} \& \mathrm{D})$ and firm performance. Our empirical analysis, based on data drawn from Nasdaq-listed companies for the period 2002 to 2017 , shows that $R \& D$ can have effects of varying magnitudes on firm performance, depending on firm size. When R\&D weakens firm performance, the negative effects are more pronounced for small-sized firms, but when the impact of R\&D is positive, leading to an improvement in firm performance from increased $R \& D$, largesized firms tend to reap most of the benefits. Accordingly, we show that firm size matters in understanding the scale of the impact of $R \& D$ on firm performance.
\end{abstract}

\section{Article info:}

Received: May 18, 2019

Correction: June 11, 2019

Accepted: July 24, 2019

\section{Keywords:}

research and development (R\&D), firm performance, firm size 


\section{INTRODUCTION}

The aim of this study is to examine how the relationship between $\mathrm{R} \& \mathrm{D}$ and firm performance might be dependent on firm size. We use data on publicly listed (Nasdaq-listed) firms from 2002 to 2017.

In today's business world, firms are constantly on the quest to maintain a competitive edge over their competitors. Most firms are faced with a tough and competitive business environment. To survive and gain a competitive edge, firms have continuously striven to develop innovative products; otherwise, they may face the risk of bankruptcy. This underscores why firms devote huge resources to research and development (R\&D) spending. It can, therefore, be inferred that how well a firm performs should be linked to its investment in R\&D. Erickson and Jacobson (1992) notes that R\&D expenditures enable firms to earn high profits and prevent imitation by rivals. Wang (2011) also postulates that firms that invest more in $\mathrm{R} \& \mathrm{D}$ earn more profits than firms which do not. $\mathrm{R} \& \mathrm{D}$ expenditure is also expected to help modernize the production process, thereby making products more appealing to buyers at home and abroad (Salim and Bloch, 2009). In the last few decades, the intensity of R\&D has increased many folds (Pandit, Wasley, and Zach, 2011). Consequently, R\&D has emerged as a key factor in promoting a firm's competitive advantage internationally.

A sizable number of empirical studies have been devoted to uncovering the likely impact of $R \& D$ on firm performance. The results from these studies are so far, however, ambiguous. While some studies reported a positive impact (see Johnson and Pazderka, 1993; Long and Ravenscraft, 1993; Lee and Shim, 1995; Monte and Papagni, 2003; Connolly and Hirschey, 2005; Ho et al., 2006; Ghaffar and Khan, 2014), others have found a negative relationship (see Gou et al., 2004; Lin and Chen, 2005; Lin et al., 2006; Artz et al., 2010; Pandit et al., 2011; Donelson and Resutek, 2012). One likely explanation for this ambiguity might be the failure to account for the contingent role that firm size plays in the R\&D-firm performance nexus. Given the plausible impact of firm size on firm performance, together with the fact that the impact of $\mathrm{R} \& \mathrm{D}$ on firm performance is still shrouded in debates and controversies, it becomes empirically imperative to ascertain whether accounting for firm size will help to better explain the rather unsettled relationship between R\&D and firm performance. This idea forms the bedrock upon which our empirical analysis rests. To this end, our study seeks to determine whether certain threshold levels of firm size exist which can help explain the conflicting relationship between $\mathrm{R} \& \mathrm{D}$ and firm performance. In other words, do large firms benefit much more when R\&D enhances firm performance? Conversely, in instances where R\&D shrinks firm performance, do large firms bear the greatest brunt or is it their smaller counterparts that bear the brunt? These are new questions in the literature, which we provide answers to in this paper.

In the literature, most of the empirical studies conducted have primarily employed correlation and multiple regression analyses (see Morbey, 1989; Morbey and Reithner, 1990; Bae and Kim, 2003; Connolly and Hirschey, 2005; Huang and Liu, 2005). These methods assume a linear relationship between $\mathrm{R} \& \mathrm{D}$ and firm performance. This means that $\mathrm{R} \& \mathrm{D}$ expenditure is expected to continually enhance or worsen firm performance across the board. Huang and Liu (2005) note that these assertions are not rational. Even though increases in $\mathrm{R} \& \mathrm{D}$ investments may generate profits, it would also result in rising R\&D costs (Shy, 1995), and potentially worsen profits and near-term firm performances before the benefits of R\&D spending begin to kick in. This suggests that the relationship between R\&D and firm performance may not be globally linear. As such, the potentially different impact of R\&D on firm performance cannot be empirically modelled using the standard multiple linear regression 
To this end, we employ the nonlinear, threshold regression model à la Hansen (1999) to model the links between $\mathrm{R} \& \mathrm{D}$ and firm performance. This technique is very appropriate when possible nonlinearities between variables are of interest. We, therefore, draw on this framework to ascertain whether the R\&D-firm performance nexus is contingent on firm size, i.e. a nonlinear relationship. In other words, we seek to uncover whether size confers an advantage on firms and, more importantly, whether large-sized firms are better positioned to reap the positive benefits of rising $R \& D$ activities over small-sized firms.

We find that the relationship between R\&D and firm performance changes for different levels of firm size. When the relationship is negative, the negative impact of $R \& D$ on firm performance is most severe for small-sized firms. On the other hand, when positive, the beneficial impact of R\&D on firm performance is most significant for large-sized firms. Our results suggest that large firms are in the best position to reap the beneficial impacts of $R \& D$ whenever they occur.

To the best of our knowledge, no study has explored the contingent role that firm size plays in the impact of $\mathrm{R} \& \mathrm{D}$ on firm performance using threshold models. The closest empirical study to our work is Ibhagui and Olokoyo (2018). Their study, however, differs in that their focus is on the role of firm size in the relationship between leverage and firm performance. Knott and Vieregger (2018) is another related study. They develop a model linking R\&D to the market value of firms. With this, they find a positive relation between $R \& D$ and market value across their full sample of firms. They also show that market value increases in $R \& D$ only for firms with $R \& D$ spending below the optimal R\&D level. Our paper differs from this study in that, rather than investigating the effects of different ranges of $R \& D$ on firm performance, we instead examine how R\&D influences firm performance when we account for differences in firm size in a nonlinear threshold modelling framework. While our result also yields a positive link between R\&D and Tobin's Q (our measure of firm market performance), the major highlight of our paper is the finding that large firms benefit more from any positive impact of R\&D on firm market performance than small firms.

Lastly, it is important to mention that our paper is different from standard studies in innovation economics, which examine the relationship between firm size and R\&D intensity, and find R\&D intensity to first increase and then decrease with firm size. Instead of focusing on firm size and R\&D intensity links, which would be a rehashing of well-studied themes in the literature, in this paper we instead focus on how firm size influences the impact of R\&D on firm performance using Nasdaq-listed companies. While the innovation economics literature documents the nonlinearity between firm size and R\&D intensity, we show, instead, that the nonlinearity is between R\&D and firm performance, with firm size acting as the threshold variable or nonlinear switcher.

The rest of the paper is organized as follows: In Section 2, we present the literature review. Section 3 presents the empirical methodology. The empirical result is reported in section 4 , while section 5 concludes the paper with suggestions for future studies. 


\section{LITERATURE REVIEW}

The empirical literature is replete with a sizable number of empirical studies on the relationship between $R \& D$ and firm performance but, so far, the available evidence and results are mixed, and largely inconclusive. $\mathrm{R} \& \mathrm{D}$ expenditure is generally considered as investments that have the potential to bring in returns in the future (Gartrell, 1990; Chauvin and Hirschey, 1993; Martınez-Zarzoso and Suarez-Burguet, 2000). Furthermore, such investments are expected to help firms maintain a competitive edge in their line of business. Despite the preponderance of empirical studies, how R\&D investments impact firm performance is still subject to divergent views. For instance, while some empirical studies find a positive impact (see Johnson and Pazderka, 1993; Long and Ravenscraft, 1993; Lee and Shim, 1995; Monte and Papagni, 2003; Connolly and Hirschey, 2005; Ho et al., 2006; Sharma, 2012), others reported contrary results (see Gou et al., 2004; Lin and Chen, 2005; Lin et al., 2006).

In the empirical study by Bae and Kim (2003) based on cross-sectional data of the U.S., Germany and Japan, a positive link is reported between $R \& D$ investments and a firm's market value. A related study by Monte and Papagni (2003) based on panel regressions also found similar results, in that R\&D intensity was reported to have a significantly positive influence on a firm's productivity. This is also in line with results reported by Ho et al. (2005). Bhagwat et al. (2001) also examined the subject matter for the case of pharmaceutical companies. Results revealed that for each $1 \%$ increase in R\&D, earnings per share will increase by one-quarter percent. On the contrary, Gou et al. (2004) find that R\&D intensity has a negative impact on a firm's profitability, while Lin and Chen (2005), in their study based on the OLS technique, report a negative correlation between $R \& D$ and firm performance measures. Czarnitzki and Kraft (2006) estimated the impact of R\&D spending on a firm's financial stress and credit ratings. This was with a view to comparing the performance of firms from Western and Eastern Germany. Results revealed that a firm's innovative activities had a positive impact on firm value in Western Germany, while a negative impact is reported for Eastern Germany. Gagic (2016) finds that innovativeness is linked to the performance of services business, such as restaurants business.

Lewin and Chew (2005) also note that increasing R\&D spending does not necessarily guarantee higher profits. While the empirical contribution by Pauwels et al. (2004) report that the introduction of new products boosts a firm's financial performance and value in the long term. This result is contrary to the empirical findings by Artz et al. (2010) in that R\&D spending was found to be positively related to patents, while a negative relationship exists between patents and firm growth, as well as between patents and return on assets. Similar results were also reported by Sher and Yang (2005), Lin et al. (2006) and Pandit et al. (2011).

In the study by Ghaffar and Khan (2014), earnings per share of firms, return on equity, and return on assets were used as firm performance measures. Empirical results report a positive correlation between R\&D and each measure of firm performance. This result is contrary to those reported by Donelson and Resutek (2012), in that R\&D expenditure was found to be negatively related to profits. In a related study by $\mathrm{Yu}$ (2017), results revealed that the effect of the first, second, and third lag of R\&D expenditure on profits is positive. Kumbhakar, Ortega-Argiles, Potters, Vivarelli and Voigt (2010), Ayam (2012) and Gui-long et al. (2017) also found similar results.

One major feature of these studies is that they are based on linear empirical techniques, thereby ignoring the possibility of threshold effects or nonlinearities in the R\&D-firm performance nexus. Our study postulates that the vague understanding that exists in the $\mathrm{R} \& \mathrm{D}$-firm performance nexus might be because the literature has largely ignored the role contingent factors play in the $\mathrm{R} \& \mathrm{D}$-firm performance nexus. 
Aside from $\mathrm{R} \& \mathrm{D}$, factors such as human resources, marketing, and financial leverage might also have an impact on firm performance (Morbey and Reithner, 1990; Erickson and Jacobson, 1992; Chauvin and Hirschey, 1993; Boer, 1994) while financial distress can impact firm management, Radjen (2015). Evidently, ever-rising R\&D spending might not result in ever-rising profits. This makes it imperative to ascertain the threshold level of $\mathrm{R} \& \mathrm{D}$ expenditure. In the literature, a good number of studies have considered contingent factors that might explain the R\&D-firm performance nexus. Those tested are labour productivity (see Morbey and Reithner, 1990), marketing intensity (see Tassey, 1983; Connolly and Hirschey, 1984; Erickson and Jacobson, 1992; Chauvin and Hirschey, 1993; Gou et al., 2004; Ho et al., 2005; Lin et al., 2006), debt structure (see Baysinger and Hoskisson, 1989; Long and Ravenscraft, 1993), firm size (see Chauvin and Hirschey, 1993; Ito and Pucik, 1993; Sterlacchini, 1999; Gou et al., 2004), export activity (see Ito and Pucik, 1993), and diversification (see Gomez-Mejia, 1992).

From the survey of the literature, it is evident that existing empirical studies majorly employed linear estimation techniques. Moreover, there is no empirical study, to the best of our knowledge, on the contingent role that firm size plays in the relationship between $R \& D$ and firm performance. This paper, therefore, seeks to address this gap in the literature by exploring the role firm size plays in the relationship between R\&D and firm performance. We employ Hansen's (1999) threshold regression model. This approach will enable us to uncover the optimal level of firm size at which R\&D improves or impedes firm performance. Unlike the Hansen (1999) model, the standard linear approach is highly restrictive, as it assumes that the impact of $R \& D$ on firm performance remains the same, irrespective of the size of a firm. In reality, this might not be true, as differences in firm sizes may alter the relationship between R\&D and firm performance. Our study enriches the literature, as well as providing fresh insights into the R\&D-firm performance nexus.

\section{EMPIRICAL METHODOLOGY}

Here, we present a description of the empirical specification, the data, summary statistics, and the main empirical results. The complete raw data used in this study is made publicly available via the following link: https://data.mendeley.com/datasets/n28bk9fpsf/3, making the results of this study reproducible.

\section{Empirical Specification}

As with studies examining the relations between economic variables, it is quite possible that the impact of R\&D on firm performance may vary with firm characteristics, such as size. In other words, how firm performance responds to additional investment in R\&D may depend on the size of the firm. It could be the case that firms need to attain a certain level of size before the beneficial effects of R\&D on their performance begin to manifest. This is a purely empirical, rather than theoretical, question that requires a flexible empirical specification to accommodate this possibility. We address this issue in this section. We examine whether the relationship between $\mathrm{R} \& \mathrm{D}$ and firm performance is contingent on firm size. Our threshold variable is, thus, firm size, while our analytical framework for the empirical specification is based on the Hansen (1999) panel threshold regression model. We seek to establish how firm size influences the relations between R\&D and firm performance. To achieve this objective, we specify the following panel threshold regression model: 


$$
F P E R_{i t}=\mu_{i}+\beta_{1}^{5} R D_{i t} I\left(D_{i t} \leq d_{1}\right)+\beta_{2}^{5} R D_{i t} I\left(D_{i t}>d_{1}\right)+\varphi^{5} \text { controls }_{i t}+\varepsilon_{i t}^{5}
$$

where $i=1, \ldots n$ signify individual firms, $t=2002, \ldots \ldots, 2017$ represents time period, FPER represents firm performance, $\mu_{i}$ is the time invariant firm specific fixed effect, $I($.) is the indicator function, while $\varepsilon_{i t}^{s}$ is the error term, $D$ is the threshold variable (firm size), and $d_{1}$ is its estimated value, the threshold value.

The empirical method used in the study is based on the Hansen (1999) threshold regression model implemented in Stata using the " $x$ threg" command. Full, detailed step-by-step information on the procedure used in the empirical analysis is provided by Wang (2015) (The Stata Journal).

\section{Data}

Our raw data samples comprise firms listed on Nasdaq during the period of 2002 to 2017. In total, we choose 476 companies with 7,616 observations. The main explanatory variable is R\&D intensity measured as total R\&D expense/net sales of listed firms. Hall and Bagchi-Sen (2007) and Ehie and Olibe (2010) note that $R \& D$ intensity is superior to absolute $R \& D$ investment amount in that the latter fails to differentiate R\&D investment of dissimilar scales enterprises.

The dependent variable in this study, firm performance, is proxied using three different measures, Tobin's Q, return on equity (ROE), and return on assets (ROA). Our study considers Tobin's Q as a proxy for market value, while the ROA and ROE measures are accounting indicators. Apart from $\mathrm{R} \& \mathrm{D}$, firm performance is also affected by a variety of internal and external variables. Therefore, we also considered two additional control variables which are marketing intensity and capital structure. Marketing-oriented companies devote a lot of resources to marketing campaigns, in addition to R\&D investments (Connolly and Hirschey, 2005). This is the main reason we included marketing intensity (total sales cost divided by the operating revenue) as one of our explanatory variables. A reasonable capital structure and appropriate debt ratio can also improve company performance and reduce financing costs. In contrast, excessive financial leverage may amplify a firm's operating risk. We, therefore, use debt-to-equity ratio to control for the impact of capital structure. Our threshold variable is firm size.

\section{Results and Discussions}

Before examining the threshold relationship, it is expedient to investigate the descriptive statistics of the variables. This shows the characteristics of the variables. Table 2 presents the descriptive statistics using concepts like mean, maximum, minimum and the standard deviation. The standard deviation, a measure of dispersion of the variables from the mean, show that the actual deviations from the mean ROA, ROE, NIG, R\&D, Size, LEV, MI and OC are minimal. Hence, the variables are stable. Moreover, the mean and standard deviations of the variables are within the minimum and maximum values. Hence, they display a high level of consistency. Overall, each variable has observation of 7,616, hence, our panel is fully balanced. 
Table 2. Descriptive Statistics of the Variables

\begin{tabular}{cccccc}
\hline \multicolumn{7}{c}{$2002-2017$} & & Max & SD \\
\hline Variable & Observations & Mean & Min & 9.55 & 1.82 \\
\hline Tobin's Q & 7616 & 1.78 & -0.49 & 2.09 & 0.59 \\
\hline ROE & 7616 & 0.02 & -3.07 & 0.31 & 0.24 \\
\hline ROA & 7616 & 0.003 & -1.31 & 10.51 & 2.71 \\
\hline NIG & 7616 & -0.05 & -9.62 & 39.39 & 3.75 \\
\hline R\&D & 7616 & 0.71 & 0 & 9.88 & 1.92 \\
\hline Size & 7616 & 5.65 & 1.71 & 0.86 & 0.18 \\
\hline Lev & 7616 & 0.13 & 0 & 0.15 & 0.03 \\
\hline MI & 7616 & 0.01 & 0 & 3.01 & 0.66 \\
\hline OC & 7616 & 0.94 & 0.01 & & \\
\hline
\end{tabular}

The interpretation further proceeds with the panel unit root test and the threshold analysis. The analytical framework for this study follows Hansen's (1999) panel threshold model. This is employed to uncover how different firm sizes might alter the relationship between $\mathrm{R} \& \mathrm{D}$ and firm performance. Before we embark on our analysis, we first ascertain whether our panel data is stationary. For this purpose, we utilize two tests, the Levin-Lin-Chu ADF (Levin et al., 2002) and the IPS ADF (Im et al., 2003) tests. In Table 1, we report the results of the panel unit root test. From the reported results, it is evident that our variables are stationary, that is, that the variables are all $\mathrm{I}(0)$ variables. Having obtained this result, we proceed with our empirical analysis.

Table 1: Panel Unit Root Test Results

\begin{tabular}{|c|c|c|c|c|}
\hline \multirow[b]{2}{*}{ Variables } & \multicolumn{2}{|c|}{ Levin-Lin Chu (LLC) } & \multicolumn{2}{|c|}{ lm, Pesaran and Shin (IPS) } \\
\hline & Statistic & $\mathrm{p}$-value & Statistic & $\mathrm{p}$-value \\
\hline Tobin's Q & $-47.89^{* * *}$ & 0.00 & $-32.75^{\star * \star}$ & 0.00 \\
\hline ROA & $-82.92^{\star * *}$ & 0.00 & $-24.32^{* * *}$ & 0.00 \\
\hline ROE & $-50.43^{\star * *}$ & 0.00 & $-62.00^{* * *}$ & 0.00 \\
\hline Firm size & $-130.00^{* * *}$ & 0.00 & $-11.46^{* * *}$ & 0.00 \\
\hline R\&D intensity & $-34.65^{\star * *}$ & 0.00 & $-4.20^{\star * *}$ & 0.00 \\
\hline Marketing intensity & $-33.27^{\star * *}$ & 0.00 & $-12.10^{* * *}$ & 0.00 \\
\hline Capital structure & $-160.00^{* * *}$ & 0.00 & $-76.18^{\star * *}$ & 0.00 \\
\hline
\end{tabular}

Note: ${ }^{* *}$ denotes significance at $1 \%$ or below.

In our empirical analysis, the bootstrap method is employed to obtain F-Statistics approximations, after which we then estimate the p-values. The results of the single threshold and double threshold tests are presented in Table 2. We repeat the bootstrap procedure several times for each panel threshold tests. The results obtained reveal that the p-values of the three proxies of firm performance, ROA, ROE, and Tobin's Q, are all significant for the single threshold model, while only the p-values of two proxies of firm performance, ROE and Tobin's Q, are significant for the double threshold model. With these results, we conclude that firm size has a significant double threshold on the relationship between R\&D and firm performance for the ROE and Tobin's Q measures of firm performance, while the ROA measure reports a single threshold. For the Tobin's Q, ROA, and ROE and measure of firm performance, the threshold estimates are $7.21,7.15$, and 2.17 respectively. 
In Table 3, we present the estimated coefficients on the regressors for each proxy of firm performance. When Tobin's $Q$ is the proxy for firm performance, we observe that the coefficient of R\&D is positive when the threshold variable - firm size, - is less than its estimated threshold value. Likewise, when the threshold variable - firm size - falls between its low and high threshold values, and when the threshold variable is above its high threshold value. We, however, report that the coefficient is insignificant when the threshold variable lies between its low and high threshold values. When ROA is the dependent variable, results show that the coefficient of $R \& D$ is negative, while when the threshold variable is less than its estimated threshold value and the same is true when it is above the estimated threshold value. The result is similar when ROE is the dependent variable. Except in the case where Tobin's Q is the dependent variable, all other proxies for firm performance reveal that the impact of R\&D on firm performance is negative, irrespective of whether the threshold variable is large, small, or between the estimated threshold values. Since Tobin's Q measures a firm's market-based performance, while ROE and ROA measure operations-based performance based on a firm's accounting or book performance alone, we conclude that $\mathrm{R} \& \mathrm{D}$ has a positive threshold effect on firm market performance, and a negative threshold effect on firm book or accounting performance.

What has clearly emerged from our empirical findings is that when $R \& D$ improves firm performance (as in the case of firm market performance), the beneficial impact is larger and most significant for large-sized firms. In other words, large-sized firms reap more from increased R\&D expenditure in instances where R\&D improves firm performance. This is explainable since larger firms have the financial capacity to attract, recruit, and maintain top-notch researchers domestically and from all around the world. In response, these researchers formulate and make breakthroughs, which lead to policies that ensure that firms reap maximally from the results of $R \& D$ through increases in sales and profitability, hence their performance. Conversely, when R\&D reduces firm performance, the negative effect is lower for large-sized firms. The results also show that small-sized firms (firm size below the estimated threshold) benefit less when R\&D improves performance, and they are most negatively affected when $R \& D$ shrinks firm performance. That is, the impact is more severe for small-sized firms when $R \& D$ weakens firm performance. This is clear from the reported coefficient values, as the negative impact is higher for small-sized firms. What this result suggests is that firms need to attain a higher firm-size level to reap the benefits or mitigate any demerits stemming from the acceleration of R\&D expenditure. In other words, the bigger a firm becomes, the more likely it benefits from any positive $\mathrm{R} \& \mathrm{D}$ effect. Lastly, one reason the response of Tobin's Q (firm market performance) to R\&D being positive is that markets often respond positively to positive news, such as a commitment to R\&D. This positive response improves companies' equities and market value, boosting firm market performance. On the other hand, ROE and ROA, which are measures of firm accounting or book performance, may first shrink on increased resources committed to R\&D in the current financial year before they subsequently begin to reflect gains from $\mathrm{R} \& \mathrm{D}$. In other words, high $\mathrm{R} \& \mathrm{D}$ may be a leading indicator for improved firm accounting or book performance. 
Table 2: Test of Threshold Effects between R\&D and Firm Performance - Threshold Variable is Firm Size

\begin{tabular}{lcccc}
\hline & & Tobin's Q & ROA & ROE \\
\hline & $\begin{array}{c}\text { Estimated threshold } \\
\text { value }\end{array}$ & 2.17 & 3.84 & 3.36 \\
\hline Single threshold effect & F-stat & $243.42^{* * *}$ & $26.19^{*}$ & $503.70^{* * *}$ \\
\hline & p-value & 0.00 & 0.06 & 0.00 \\
\hline & $\begin{array}{c}\text { Estimated threshold } \\
\text { value I }\end{array}$ & 2.17 & 3.84 & 3.36 \\
\hline Double threshold effect & $\begin{array}{c}\text { Estimated threshold } \\
\text { value II }\end{array}$ & 7.21 & 7.25 & 2.17 \\
\hline & F-stat & $234.15^{* * *}$ & 10.7 & $125.08^{* * *}$ \\
\hline & p-value & 0.00 & 0.38 & 0.00 \\
\hline & Final Comments & $\begin{array}{c}\text { Double thresh- } \\
\text { old points }\end{array}$ & $\begin{array}{l}\text { Singlethreshold } \\
\text { point }\end{array}$ & $\begin{array}{c}\text { Double threshold } \\
\text { points }\end{array}$ \\
\hline
\end{tabular}

Note: F-statistics and p-values come from repeated bootstrap procedures, ${ }^{* * *}$, ${ }^{* *}$, and ${ }^{*}$ represent significance at $1 \%, 5 \%$ and $10 \%$ levels, respectively

Table 3: Estimated Coefficients of the Effect of R\&D on Firm Performance at the Threshold Points

\begin{tabular}{|c|c|c|c|c|c|}
\hline & Coefficients & Estimated coefficient & t-stat & Robust se & $R^{2}$ \\
\hline \multirow[t]{3}{*}{ Tobin's Q } & $\beta_{0}$ & $0.40^{* * *}$ & 5.50 & 0.73 & 0.73 \\
\hline & $\beta_{1}$ & 0.016 & 0.28 & 0.06 & 0.06 \\
\hline & $\beta_{2}$ & $1.60^{* * *}$ & 3.63 & 0.44 & 0.44 \\
\hline \multirow[t]{2}{*}{ ROA } & $\beta_{0}$ & $-0.10^{* * *}$ & -8.65 & 0.01 & 0.01 \\
\hline & $\beta_{1}$ & $-0.07^{* * *}$ & -8.32 & 0.01 & 0.01 \\
\hline \multirow[t]{3}{*}{ ROE } & $\beta_{0}$ & $-0.12^{\star * \star}$ & -10.82 & 0.01 & 0.01 \\
\hline & $\beta_{1}$ & $-0.08^{* * *}$ & -7.97 & 0.01 & 0.01 \\
\hline & $\beta_{2}$ & $-0.03^{* * *}$ & -4.16 & 0.03 & 0.03 \\
\hline
\end{tabular}

Note: In the case of 2 threshold points, $\beta_{0}$ represent the coefficient of R\&D when the threshold variable, firm size, is less that its smaller threshold value; $\beta_{1}$ is the coefficient when the threshold variable, which falls between its smaller and larger threshold values, while $\beta_{2}$ is the coefficient when the threshold variable is above its larger threshold value. In the case of one threshold point, $\beta_{0}$ is the R\&D coefficient when firm size, the threshold variable, is below the estimated threshold value, while $\beta_{1}$ is the coefficient when the threshold variable is greater than the threshold variable. 
This paper also captures the likely impact of the control variables - marketing intensity, firm size, and capital structure - on firm performance. The results are presented in Table 4 and show that firm size has a significant negative impact on firm performance. This result may be due to the period and firms selected, and is akin to the outcome often obtained when firm size is specified linearly. Another plausible explanation for this counterintuitive negative effect of firm size is that when firms become large, they naturally come under the control of different sorts of managers, some of whom pursue their self-interests at the expense of business-related or firm-wide interests. As such, core performance maximization that enhances firm overall performance may be indirectly replaced with inefficiencies and manager-friendly, but performance-destructive, policies, thus dampening firm performance, even as firm grows. Furthermore, the negative result also implies that the failure of big firms to increase capital structure ratio, having increased their size, may lead to of sub-optimal financial management. In addition, it possibly highlights the nonlinearities in the effect of firm size on firm performance wherein firm size positively affects performance for some firm size ranges and negative for others. This kind of outcome has been well explored in Pervan and Višić (2012). Meanwhile, marketing intensity and capital structure have an insignificant negative impact when Tobin's Q serves as the proxy for firm performance. Furthermore, when ROA serves as the dependent variable, capital structure and firm size had significant negative impacts, while marketing intensity reported an insignificant negative impact. For the ROE proxy for firm performance, we report that firm size had a significant positive impact on firm performance, while capital structure and marketing intensity reported a significant negative impact.

Table 4: Impacts of Other Covariates (Control Variables) on Firm Performance

\begin{tabular}{ccccc}
\hline & & \multicolumn{3}{c}{ Firm Performance Measures } \\
\hline & & Tobin's Q & ROA & ROE \\
\hline & Capital structure & -0.01 & $-0.08^{* *}$ & $-0.23^{* * *}$ \\
\hline Control Variables & Firm size & $(-0.02)$ & $(-2.05)$ & $(-15.05)$ \\
\hline & Marketing intensity & $-0.31^{* * *}$ & $-0.13^{* * *}$ & $0.03^{* * *}$ \\
\hline & $(-10.94)$ & $(-14.65)$ & -10.46 \\
\hline & -1.23 & -0.28 & $-0.88^{* * *}$ \\
\hline & $(-0.88)$ & $(-0.79)$ & $(-4.76)$ \\
\hline F-stat & & & \\
\hline & p-val & 27.09 & 57.67 & 70.71 \\
\hline$R^{2}$ & 0.00 & 0.00 & 0.00 \\
\hline No of observations & 0.21 & 0.05 & 0.25 \\
\hline
\end{tabular}

Note: The impact of control variables on firm performance is reported, alongside the t-statistic in (). ${ }^{* *},{ }^{* *}$, and ${ }^{\star}$ signify significance at $1 \%, 5 \%$, and $10 \%$ levels.

Our main takeaway consists of two parts. First, when R\&D improves firm performance, the beneficial impact is most significant when the firm size is large. Second, when R\&D is negatively associated with firm performance, the effect is most severe for small-sized firms. In other words, small-sized firms are hit the hit when $R \& D$ weakens firm performance. Thus, large-sized firms benefit more from increases in $R \& D$. From the foregoing, any view that large firms do not benefit more from increases in R\&D appears to be unjustified. According to the results, small-sized firms, in fact, have more to worry about, as they benefit less when $R \& D$ enhances performance, and usually bear the brunt when $R \& D$ worsens firm performance. 
Our results are quite instructive, especially for business managers and policymakers, as they propose that discussions on firm size should be a board room standard when decisions on R\&D are being made. Our paper enriches the literature, in addition to providing fresh insights and perspectives that will be of immense benefit to policymakers, researchers, and business managers. To our knowledge, no previous study has considered the contingent role that firm size plays in the link between $R \& D$ and the performance of publicly-listed NASDAQ firms.

\section{CONCLUSION}

In this study, we have attempted to answer an important economic decision question: does firm size matter in the relationship between $\mathrm{R} \& \mathrm{D}$ and firm performance? This is with a view to uncovering how firm size might provide more insights into the relationship between R\&D and firm performance. Our empirical analysis employs data from firms listed on Nasdaq during the period of 2002 to 2017. In total, we have 476 companies with 7,616 observations. Three proxies of firm performance are employed: Tobin's Q, ROE, and ROA. Our explanatory variable of interest is R\&D intensity and firm size (the threshold variable); we also included control variables, such as marketing intensity and capital structure. For the specification of our empirical analysis, we have employed Hansen's (1999) threshold regression model.

From the empirical findings, firm size matters in the relationship between R\&D and firm performance. In specific terms, we find that in instances where R\&D worsens firm performance, the negative impact is most evident in small-sized firms. Large-sized firms, on the other hand, benefit more when $R \& D$ improves firm performance. When firm performance is proxied with Tobin's $Q$, the gains from R\&D improve as firm size becomes larger. On the contrary, when ROA and ROE are proxies of firm performance, the negative impact of R\&D becomes worse as firm size becomes smaller.

We recommend that future studies control for other plausible determinants of firm performance. It is also important to extend this analysis to firms listed on the exchanges of other countries, subregions, and economic blocs. Future studies should also include a wider array of plausible thresholds and controls in the threshold model and investigate the potential lead-lag relations between R\&D and firm performance, especially for the accounting firm performance measures, such as ROA and ROE. At this juncture, it is necessary to emphasize that, as the investigation performed in this paper relates to Nasdaq-listed companies alone, future studies could perform further similar investigations on firms listed on other exchanges. 


\section{REFERENCES}

Ayam, R. T. (2012). Research and development and firm performance: Investigating the need for research and development expenditure as a factor of enhancing the performance of firms.

Adegbite, S. A. (2012). An evaluation of technology innovation on the performance of indigenous textile weaving firms in southwestern Nigeria. Journal of Business and Management Volume 1, Issue 1, 01-14.

Adeyeye, A. D., Jegede, O. O. and Akinwale, Y. O. (2013). The impact of technology innovation and R\&D on firms' performance: an empirical analysis of Nigeria's service sector, International Journal of Technological Learning, Innovation and Development, Vol. 6, No. 4, 374-395.

Artz, K. W., Norman, P. M., Hatfield, D. E. and Cardinal, L. B. (2010). A longitudinal study of the impact of $\mathrm{R} \& \mathrm{D}$, patents, and product innovation on firm performance. Journal of Product Innovation Management, 27(5), 725-740.

Bae, S. C. and Kim, D. (2003). The effect of R\&D investment on market value of firm: evidence from the U.S., Germany, and Japan. Multinational Business Review, 11, 51-75.

Baysinger, B. D. and Hoskisson, R. E. (1989). Diversification strategy and R\&D intensity in large multi-product firms, Academy of Management Journal, 32, 310-12.

Bhagwat, Y., DeBruine, M. and Gondhalekar, V. (2001). R\&D Leverage - A Measure to Evaluate the Impact of R\&D on Earnings of Pharmaceutical Companies, Journal of Research in Pharmaceutical Economics, $11(3-4), 55-68$.

Boer, F. P. (1994). Linking R\&D to growth and shareholder value, Research Technology Management, 37, 16-22.

Chauvin, K. W. and Hirschey, M. (1993). Advertising, R\&D expenditures and market value of the firm, Financial Management, 22, 128-40.

Chu, H., Sher, P. J. and Chiu, Y. (2010). R\&D intensity, firm performance and the identification of the threshold: fresh evidence from the panel threshold regression model, Applied Economics, 42:3, 389-401.

Connolly, R. A. and Hirschey, M. (2005). Firm size and the effect of R\&D on Tobin's q, R\&D Management, 35, 217-23.

Czarnitzki, D. and Kraft, K. (2012). Spillovers of innovation activities and their profitability. Oxford Economic Papers, 64(2), 302-322.

Donelson, D. C. and Resutek, R. J. (2012). The effect of R\&D on future returns and earnings Forecasts, Springer Science+Business Media, LLC.

Ehie, I. and Olibe, K. (2010). The effect of R\&D investment on firm value: An examination of US manufacturing and service industries. International Journal of Production Economics, 128(1), 127-135.

Erickson, G. and Jacobson, R. (1992). Gaining comparative advantage through discretionary experience: the returns to R\&D and advertising, Management Science, 38, 1264-79.

Gartrell, K. D. (1990). Innovation, industry specialization and stockholder wealth, California Management Review, 32, 87-101.

Gagic, Snježana (2017). Restaurant Innovativeness: A Case Study of Vojvodina. In European Journal of Applied Economics, 13, 2, 57-69.

Ghaffar, A. and Khan, W. A. (2014). Impact of research and development on firm performance International Journal of Accounting and Financial Reporting, Vol. 4, No. 1.

Gomez-Mejia, L. R. (1992). Structure and process of diversification, compensation on strategy, and firm performance, Strategic Management Journal, 13, 381-97.

Gou, B., Wang, Q. Z. and Shou, Y. Y. (2004). Firm size, R\&D, and performance: An empirical analysis on software industry in China, in International Engineering Management Conference 2004, IEEE, Singapore.

Gui-long, Z., Yi, Z., Kai-hua, C. and Jiang, Y. (2017). The impact of R\&D intensity on firm performance in an emerging market: Evidence from China's electronics manufacturing firms, Asian Journal of Technology Innovation, DOI: 10.1080/19761597.2017.1302492 
Hall, L. A. and Bagchi-Sen, S. (2007). An analysis of firm level innovation strategies in the U. S. biotechnology industry. Technovation, 27(1-2):4-14.

Hansen, B. E. (1999). Threshold effects in non-dynamic panels: estimation, testing, and inference. Journal of Econometrics, 93, 345-368.

Ho, H. K., Tjahjapranta, M. and Yap, C. M. (2006). Size, leverage, concentration, and R\&D investment in generating growth opportunities, Journal of Business, 79, 851-76.

Huang, C. J. and Liu, C. J. (2005). Exploration for the relationship between innovation, IT and performance, Journal of Intellectual Capital, 6, 237-52.

Ibhagui, Q. W. and Olokoyo, F. O. (2018). Leverage and firm performance: New evidence on the role of firm size. North American Journal of Economics and Finance (2018), https://doi.org/10.1016/j.najef.2018.02.002

Im, K. S., Pesaran, M. H. and Shin, Y. (2003). Testing for unit roots in heterogeneous panels, Journal of Econometrics, 115, 53-74.

Ito, K. and Pucik, V. (1993). R\&D spending, domestic competition, and export performance of Japanese manufacturing firms, Strategic Management Journal, 14, 61-75.

Johnson, I. D. and Pazderka, B. (1993). Firm value and investment in R\&D, Managerial and Decision Economics, $14,15-24$.

Kumbhakar, S. C., OrtegaArgilés, R., Potters, L., Vivarelli, N. and Voigt, P. (2010). How corporate R\&D affects firms' productivity: Empirical evidence and toehold for targeted policy measures. Contributed paper for the 2nd Conference on corporate R\&D (CONCORD - 2010).

Knott, A. M., and Vieregger, C., (2018). A Theory of R\&D When Firms Differ. Available at SSRN: https://ssrn. com/abstract=2382885 or http://dx.doi.org/10.2139/ssrn.2382885.

Lee, J. and Shim, E. (1995). Moderating effects of R\&D on corporate growth in U.S. and Japanese hi-tech industries: an empirical study, The Journal of High Technology Management Research, 6, 179-91.

Lee, J. and Shim, E. (1995). Moderating effects of R\&D on corporate growth in U.S. and Japanese hi-tech industries: an empirical study, The Journal of High Technology Management Research, 6, 179-91.

Levin, A., Lin, C. F. and Chu, C. S. (2002). Unit root tests in panel data: asymptotic and finite-sample properties, Journal of Econometrics, 108, 1-24.

Lewin, T. and Chew, E. (2005). High R\&D, greater profits. Automotive News Europe, 10(23), 1 \& 26.

Lin, B. W. and Chen, J. S. (2005). Corporate technology portfolios and R\&D performance measures: A study of technology intensive firms, R\&D Management, 35, 157-70.

Lin, B., Lee, Y. and Hung, S. (2006). R\&D intensity and commercialization orientation effects on financial performance, Journal of Business Research, 59, 679-85.

Long, W. F. and Ravenscraft, D. J. (1993). LBO’s debt and R\&D intensity, Strategic Management Journal, 14, 119-35.

Martınez-Zarzoso, I. and Suarez-Burguet, C. (2000). The determinants of trade performance: influence of R\&D on export flows, Applied Economics, 32, 1939-46.

Monte, A. D. and Papagni, E. (2003). R\&D and the growth of firms: Empirical analysis of a panel of Italian firms, Research policy, 32, 1003-14.

Morbey, G. K. (1989). R\&D expenditures and profit growth, Research Technology Management, 32, 20-23.

Morbey, G. K. and Reithner, R. M. (1990). How R\&D affects sales growth, productivity and profitability, Research Technology Management, 33, 11-15.

Pandit, S., Wasley, C. E. and Zach, T. (2011). The effect of research and development (R\&D) inputs and outputs on the relation between the uncertainty of future operating performance and R\&D expenditures. Journal of Accounting, Auditing and Finance, 26(1), 121-144.

Pauwels, K., Silva-Risso, J., Srinivasan, S. and Hanssens, D. M. (2004). New products, sales promotions, and firm value: The case of the automobile industry. Journal of Marketing, 68(4), 142-156. http://dx.doi.org/10.1509/ jmkg.68.4.142.42724 
Pervan M. and Visic J. (2012), Influence of firm size on its business success. Croatian Operational Research Review (CRORR), Vol. 3, 2012

Pitelis, C. N. (2009). Edith Penrose's, “The theory of the growth of the firm' fifty years later. Available at http:// ssrn.com/abstract $=1477885$

Radjen, D. (2015). The Analysis of the Effects of Financial Distress on the Top Management in the Republic of Serbia. The European Journal of Applied Economics, 12(1), 19-25. https://doi.org/10.5937/ejae12-7977.

Salim, R. A. and Bloch, H. (2009). Business expenditures on R\&D and trade performances in Australia: is there a link? Applied Economics, 41(3), 351-361.

Sharma, C. (2012). R\&D and firm performance: Evidence from the Indian pharmaceutical industry. Journal of the Asia Pacific Economy, Vol. 17, No. 2, May 2012, 332-342.

Sher, P. J. and Yang, P. Y. (2005). The effects of innovative capabilities and R\&D clustering on firm performance: The evidence of Taiwan's semiconductor industry. Technovation, 25(1), 33-43. http://dx.doi.org/10.1016/ S0166-4972 (03)00068-3

Shy, O. (1995). Industrial organization: Theory and applications. The MIT Press.

Sterlacchini, A. (1999). Do innovative activities matter to small firms in non-R\&D-intensive industries? An application to export performance, Research Policy, 28, 819-32.

Tassey, G. (1983). Competitive strategies and performance in technology-based industries, Journal of Economic Business, 36, 21-40.

Wang, C. H. (2011). Clarifying the effects of R\&D on performance: Evidence from the high technology industries. Asia Pacific Management Review, Vol. 16, No. 1, 51-64.

Wang, Q., (2015). Fixed-Effect Panel Threshold Model Using Stata, Stata Journal, 15(1), 121-134.

Yu, Z. (2017). R\&D Expenditure and Firm Performance in China. Major Paper presented to the Department of Economics of the University of Ottawa in partial fulfillment of the requirements of the M.A. Degree. 


\section{APPENDIX 1}

\section{The Threshold Model}

This model is nonlinear in that it captures instances where the relationship between variables might be different at certain sections of the data. The model also allows us to split the data sample into two regimes, $D<d_{1}$ and $D>d_{1}$ for all values of $R \leftrightarrow D$, where $D$ is the threshold variable (firm size) and $d_{1}$ is its estimated value, the threshold value. Our threshold variable is $D \in V$ where $V$ is a vector of all regressors. It is this threshold variable that divides the data samples into different regimes. $d_{1}$, on the other hand, is the threshold values associated with $D$. In this study, we adopt firm size as the threshold variable, since we are interested in how R\&D weakens firm performance for varying levels of firm size.

In this paper, our regressors of interest are return on asset (ROA), return on equity (ROE), and Tobin's Q. Taking a cue from Hansen (1999), we formulate a model where the regressors, control, and threshold variables are exogenous. The panel threshold regression model is specified as:

$y_{i t}=\beta_{1}^{\prime} x_{i} I\left(p_{i} \leq \gamma\right)+\beta_{2}^{\prime} x_{i}\left(p_{i}>\gamma\right)+v_{t}$

where $v_{i t}=\mu_{i}+e_{i}$

We draw the observed data samples from a panel $\left(y_{i t}, p_{i}, x_{i} ; 1 \leq i \leq n, 1 \leq t \leq T\right) . i$ and $t$ represent firm and time, while $x_{i t}$ is a set of regressors. The threshold variable is $p_{i t}$, which can be a member of $x_{i t}$, while refers to the unobserved time invariant fixed effects.

The equation specified above can be re-written as

$y_{i t}=\mu_{i}+\beta_{1}^{\prime} x_{i} I\left(p_{i} \leq \gamma\right)+\beta_{2}^{\prime} x_{i}\left(p_{i}>\gamma\right)+e_{i}$

where $y_{i t}$ is a real-valued scalar variable, $x_{i t}$ is an $\mathrm{m} \times 1$ vector of regressors, $p_{i t}$ is a scalar threshold variable with $\operatorname{Dim}\left(y_{i t}\right)=\operatorname{Dim}\left(p_{t}\right)$, while the unobserved threshold value is $\gamma$. The vectors of slope parameters associated with the different regimes are $\beta_{1}^{\prime}$ and $\beta_{2}^{\prime}$ where

$A=\left\{p_{i t} \mid\left(p_{i} \leq \gamma\right)\right\}$ and $B=\left\{p_{i t} \mid\left(p_{i}>\gamma\right)\right\}$

while $I($.$) is the indicator function defined for an arbitrary element d$ in a set $A \cup B$

The equation specified above gives rise to two possibilities. These possibilities depended on whether $d \in\left\{p_{i t} \mid\left(p_{i} \leq \gamma\right)\right\} \quad$ or $d \in\left\{p_{i t} \mid\left(p_{i}>\gamma\right)\right\}$, which in turn yields the two regimes specified below:

$y_{i t}=\left\{\begin{array}{l}\mu_{i}+\beta_{1}^{\prime} x_{i}+e_{i} p_{i} \leq \gamma \\ \mu_{i}+\beta_{1}^{\prime} x_{i}+e_{i} p_{t}>\gamma\end{array}\right.$ 
This equation can also be re-written such that both regimes are now expressed in a compact manner. In this specification, the regressors and thresholds are represented in a column vector, while the slope parameters are set in a row vector. This can be expressed as:

$$
\begin{aligned}
& y_{i t}=\mu_{i}+\left(\beta_{1}^{\prime}, \beta_{2}^{\prime}\right)\left(\begin{array}{l}
x_{i} I\left(p_{i} \leq \gamma\right) \\
x_{i} I\left(p_{i}>\gamma\right)
\end{array}\right)+e_{i} \\
& y_{i t}=\mu_{i}+\beta^{\prime} x_{i}(\gamma)+e_{i}
\end{aligned}
$$

We divide $\beta^{\prime}=\left(\beta_{1}^{\prime}, \beta_{2}^{\prime}\right)$ and $x_{i t}=\left(\begin{array}{l}x_{i} I\left(p_{i} \leq \gamma\right) \\ x_{i} I\left(p_{i}>\gamma\right)\end{array}\right)$ into two regimes where the threshold variable is at most its threshold value, and when the threshold variable is above its threshold value. In what follows, we estimate the slopes of $\beta_{1}^{\prime}$ and $\beta_{2}^{\prime}$. We reiterate that the error component has been divided into two parts where $e_{i t}$ is assumed to be an independent and identically distributed (iid) with constant and finite variance. This assumption requires that the threshold variable and regressors eliminate endogenous variables, which may correlate with the error term. Hence, $e_{i t}$ is a martingale difference sequence $\left\{e_{i t}, F_{t}\right\}$ on the probability space $(\Omega, F, P)$ for each $i$ since $E\left(e_{i t}\right)=0<\infty$ and $E\left(e_{i t} \mid F_{t-1}\right)=0$ where $F_{t-1}$ is a natural filtration at time $t$. Likewise, $E\left(e_{i t} \mid p_{i}\right)=E\left(e_{t} \mid x_{i}\right)=0$ and $\left(x_{i t}, p_{i}\right)$ are measurable with respect to $F_{t-1}$ where $F_{t-1}$ is the sigma field generated by $\mathrm{N}=\left\{\mathrm{x}_{(\mathrm{i}-\mathrm{j}) \mathrm{t}}, p_{(i o-j) t}, e_{(i-1-j) t}: j \geq 0\right\}$

\section{Estimating the Model}

As a first step in estimating the model specified above, we eliminate firm specific effects, . This is done using within transformation in which contemporaneous observations are subtracted from the within group average for each variable. The transformation of equation (1.1) yields:

$y_{i t}^{\perp}=\beta_{t}^{\perp} x_{i}(\gamma)+e_{i}^{\perp}$

where $y_{i t}^{\perp}=\left(y_{i}-\frac{1}{T} \sum_{t=1}^{T} y_{i}\right), e_{i}^{\perp}=\left(e_{i}-\frac{i}{T} \sum_{t=1}^{T} e_{i}\right)$ and $\beta^{\prime}=\left(\beta_{1}^{\prime}, \beta_{2}^{\prime}\right)$

and $x_{i t}^{\perp}=\left(\begin{array}{l}\left(x_{i} I\left(p_{i} \leq \gamma\right)-\frac{1}{T} \sum_{t=1}^{T}\left(x_{i} I\left(p_{i} \leq \gamma\right)\right.\right. \\ \left(x_{i} I\left(p_{i}>\gamma\right)-\frac{1}{T} \sum_{t=1}^{T}\left(x_{i} I\left(p_{i}>\gamma\right)\right.\right.\end{array}\right)$

In the equation specified below, we denote the errors and stacked data connected with firm $i$, with one-time period deleted as in Hansen (1999): 


$$
y_{i}^{\perp}=\left(\begin{array}{c}
y_{i 2}^{\perp} \\
\cdot \\
\cdot \\
\cdot \\
y_{i T}^{\perp}
\end{array}\right), x_{i}^{\perp}(\gamma)=\left(\begin{array}{l}
x_{i 2}^{\perp}(\gamma)^{\prime} \\
\cdot \\
\cdot \\
\cdot \\
x_{i T}^{\perp}(\gamma)^{\prime}
\end{array}\right), e_{i}^{\perp}=\left(\begin{array}{c}
e_{i 2}^{\perp} \\
\cdot \\
\cdot \\
\cdot \\
e_{i T}^{\perp}
\end{array}\right)
$$

Also, we denote data stacked over all firms as $Y^{\perp}, X^{\perp}$ and $e^{\perp}$ where:

$$
Y^{\perp}=\left(\begin{array}{c}
y_{2}^{\perp} \\
\cdot \\
\cdot \\
\cdot \\
y_{t}^{\perp} \\
\cdot \\
\cdot \\
\cdot \\
y_{n}^{\perp}
\end{array}\right), x^{\perp}(\gamma)=\left(\begin{array}{c}
x_{2}^{\perp}(\gamma)^{\prime} \\
\cdot \\
\cdot \\
\cdot \\
x_{t}^{\perp}(\gamma)^{\prime} \\
\cdot \\
\cdot \\
\cdot \\
x_{n}^{\perp}(\gamma)^{\prime}
\end{array}\right), e^{\perp}=\left(\begin{array}{c}
e_{i 2}^{\perp} \\
\cdot \\
\cdot \\
\cdot \\
e_{t}^{\perp} \\
\cdot \\
\cdot \\
\cdot \\
e_{n}^{\perp}
\end{array}\right)
$$

This can be re-specified as: $Y^{\perp}=X^{\perp}(\gamma) \beta+e^{\perp}$

The assumptions guiding the original equation are reflected in the transformed equation. We can therefore estimate $\beta$ using least squares for any which in turn yields:

$$
\hat{\beta}(\gamma)=\left(X^{\perp}(\gamma) X^{\perp}(\gamma)^{-1} X^{\perp}(\gamma) Y^{\perp}\right)
$$

From this estimated equation, we can obtain the vector of regression residuals from the threshold dependent slope parameter. This is specified as:

$$
\hat{e}^{\perp}(\gamma)=Y^{\perp}-X^{\perp}(\gamma) \beta(\gamma)=Y^{\perp}-X^{\perp}\left(\gamma \chi X^{\perp}(\gamma) X^{\perp}(\gamma){ }^{-1} X^{\perp}(\gamma) Y^{\perp}\right)
$$

Subsequently, we use the regression residual to compute the sum of errors. Following Hansen (1999), the threshold value $\gamma$, which determines the sample split is estimated by least squares. Thus, we find $\hat{\gamma} \gamma$ that minimizes the concentrated sum of squared errors, such that the least squares estimator of $\hat{\gamma}={ }_{\gamma} \arg \min S_{1}(\gamma)^{1}$. We have the parameter estimate as $\hat{\beta}=\hat{\beta}(\hat{\gamma})$ after obtaining $\hat{\gamma}$. The slope parameters estimated at the different regimes partitioned by $\hat{\gamma}$ is $\hat{\beta}(\hat{\gamma})$. Thus, $\hat{\beta}_{1}$ and $\hat{\beta}_{2}$ represents the vector of slopes associated with the regimes $I\left(p_{i t} \leq \hat{\gamma}\right)$ and $I\left(p_{i t}>\hat{\gamma}\right)$. Furthermore, we partition the data sample into regimes after obtaining the estimate $\hat{\gamma}$ of the threshold value $\gamma$. As a final step, we estimate the final slope parameters associated with the regimes, which in turn yields $\bar{\beta}_{1}=\bar{\beta}_{1}(\hat{\gamma})$ for $I\left(p_{i t} \leq \hat{\gamma}\right)$ and $\hat{\beta}_{2}(\hat{\gamma})$ for $I\left(p_{i t}>\hat{\gamma}\right)$. 


\section{APPENDIX 2}

\section{Correlation Matrix}

Table I: Cross Correlation Matrix

\begin{tabular}{|c|c|c|c|c|c|c|c|}
\hline & Tobin's Q & $\mathrm{ROE}$ & ROA & $\mathrm{R} \& \mathrm{D}$ & Size & Lev & MI \\
\hline Tobin's Q & 1 & & & & & & \\
\hline $\mathrm{ROE}$ & $-0.034^{\star * *}$ & 1 & & & & & \\
\hline $\mathrm{ROA}$ & $-0.192^{\star * *}$ & $0.463^{* * *}$ & 1 & & & & \\
\hline $\mathrm{R} \& \mathrm{D}$ & $0.151^{\star * *}$ & $-0.186^{\star * *}$ & $-0.453^{\star * *}$ & 1 & & & \\
\hline Size & $-0.106^{\star * *}$ & $0.238^{* * *}$ & $0.420^{* * *}$ & $0.144^{\star * *}$ & 1 & & \\
\hline Lev & $0.055^{\star * *}$ & $0.033^{* * *}$ & $-0.090^{* * *}$ & $0.038^{* * *}$ & $0.220^{* * *}$ & 1 & \\
\hline MI & $0.023^{\star *}$ & $0.020^{*}$ & 0.017 & $0.046^{* * *}$ & $0.097^{\star * *}$ & $0.023^{\star *}$ & 1 \\
\hline
\end{tabular}

\section{II .Definition of Variables}

Table II. Variable Definition

\begin{tabular}{ccc}
\hline Variable Type & Variable Name & Variable Explanation \\
\hline Dependent Variable & Tobin's Q & Market value over book value \\
\hline & ROE & Return on common equity \\
\hline ROA & Return on total assets \\
\hline Independent Variable & R\&D & R\&D expenditure/Sales turnover \\
\hline Control Variable & Size & Log (Turnover) \\
\hline Lev & Capital structure: Debt/Equity \\
\hline MI & Marketing expenditure/Sales turnover \\
\hline
\end{tabular}




\section{DA LI VELIKE FIRME OSETE ZNAČAJNIJI BOLJITAK OD INVESTICIJA U VEZI SA ISTRAŽIVANJEM I RAZVOJEM?}

\section{Rezime:}

$\mathrm{U}$ radu smo analizirali važnost veličine firme u odnosu u kojem se nalaze istraživanje i razvoj, s jedne i učinak firme, s druge strane. Naša empirijska analiza, zasnovana na podacima dobijenim iz kompanija koje su deo popisa Nasdaq, u periodu 2002-2017. godina, pokazuju da istraživanje i razvoj mogu da imaju uticaj na razlike u učinku firme, u zavisnosti od same njene veličine. Kada ulaganje $u$ istraživanje i razvoj oslabi učinak firme, negativni efekti su više primetni u malim firmama, ali kada ulaganje u istraživanje i razvoj ima pozitivan efekat, koji dovodi do napretka u samom učinku firme, upravo iz navedenog razloga, velike firme najviše osećaju sav boljitak ovog procesa. U vezi sa tim, potvrdili smo da veličina firme jeste važna kada je u pitanju razumevanje stepena uticaja istraživanja i razvoja na sam učinak firme.

Ključne reči:

istraživanje i razvoj, učinak firme, veličina firme 